\title{
The effects of parturition season and suckling mode on the puerperium of Santa Ines ewes and on the weight gain of lambs
}

\author{
[Efeitos do período das parições e dos sistemas de amamentação sobre o puerpério de ovelhas \\ Santa Inês e desempenho ponderal de cordeiros]

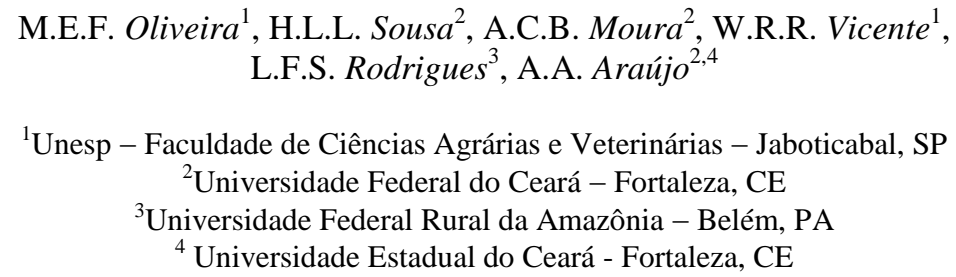

\section{ABSTRACT}

Seventy-seven ewes were randomly divided into groups according to parturition season and suckling mode [Rainy season: continuous $(n=14)$ and controlled $(n=13)$; Dry season: continuous $(n=25)$ and controlled $(n=25)]$. The controlled suckling mode, in both seasons, resulted in a decrease in variables, intervals between parturition and first estrus (reduction of 27.11 and 11.46 days for rainy and dry season, respectively; $\mathrm{P}<0.05$ ) and between parturition and estrus of conception (reduction of 12.81 and 13.58 days, for rainy and dry season, respectively; $\mathrm{P}<0.05$ ). As to the lambs, the weight gain was higher in animals subjected to controlled suckling in relation to continuous, especially when lambing occurred in the rainy season $(17.83 \pm 0.56$ vs. $13.95 \pm 0.52 \mathrm{~kg}$ for Lambs' weight at 90 days old, respectively; $\mathrm{P}<0.05)$. Therefore, it was concluded that controlled suckling management is better indicated for the Amazonian region, since it allows the ewes to have a shorter puerperium period and the lambs exhibit higher weight gain.

Keywords: sheep, suckling, puerperium, weight gain

\section{RESUMO}

Foram utilizadas 77 ovelhas, divididas aleatoriamente em grupos de acordo com o período de parição e o manejo de amamentação [chuvoso: contínua $(n=14)$ e controlada $(n=13)$; seco: contínua $(n=25) e$ controlada (n=13)]. O sistema de amamentação controlado, em ambos os períodos, resultou em decréscimo para as variáveis intervalos entre parto e primeiro estro (redução de 27,11 e 11,46 dias para os períodos chuvoso e seco, respectivamente; $P<0,05)$ e entre parto e estro da concepção (redução de $12,81$ e 13,58 dia para os períodos chuvoso e seco, respectivamente; $P<0,05)$. Quanto ao desempenho ponderal dos cordeiros, o ganho de peso foi maior para os animais submetidos ao regime de amamentação controlada em relação à contínua, especialmente quando os nascimentos ocorreram no período chuvoso $(17,83 \pm 0,56$ vs. $13,95 \pm 0,52 \mathrm{~kg}$ para o peso dos cordeiros aos 90 dias de idade, respectivamente; $\mathrm{P}<0,05)$. Contudo, o manejo de amamentação controlada é indicado para a região amazônica, por permitir menor tempo de puerpério das ovelhas e maior ganho de peso dos cordeiros.

Palavras-chave: amamentação, clima, puerpério, ganho de peso, ovinos

\section{INTRODUCTION}

The main objective of the sheep industry is meat production. In these systems, the resumption of cyclicity during puerperium is, without a doubt,

Recebido em 30 de julho de 2012

Aceito em 25 de janeiro de 2013

E-mail: m_emiliafraoli@yahoo.com.br one of the major factors that interfere with the reproductive efficiency of the herd. The reduction in intervals between parturition intensifies the production process since it increases the number of offspring/female/year and, consequently, there is an increase in profitability. 
The interval between parturition and the resumption of normal cycles depends on a number of factors (Mandiki et al., 1990). Suckling is described as the major cause directly involved with duration of postpartum anestrus (Azevedo et al., 2002; Hayder and Ali, 2008). Frequency and intensity of suckling adversely affect the resumption of ovarian activity (Ronquillo et al., 2008).

Physiologically, the stimulus of suckling teats increases the concentrations of oxytocin and, consequently, of prolactin (Negrão et al., 2001). In turn, high concentrations of prolactin inhibits the discharge of the gonadotropin releasing hormone $(\mathrm{GnRH})$, which do not stimulate the secretion of the luteinizing hormone (LH) and regulates resumption of cyclicity (Yavas and Walton, 2000). Thus, controlled suckling has been studied as a potential tool to increase efficiency in production systems (Morales-Terán et al., 2004; Costa et al., 2007).

The climatic factors are also intimately related to reproductive and productive performances in animals. A series of variations are observed according to the region in which they are raised. The Amazonian climate is known to have intense rainfall associated to high temperatures and humidity throughout the year. This combination can cause intense discomfort to animals (Costa et al., 2010), as well as interfere with the production management as a whole (i.e. pasture availability, grazing time and occurrence of related diseases). Even though these climatic conditions seem to be unfavorable at first, the Amazonian region presents great animal production potential. Livestock production has been rapidly intensifying in the region throughout the years (IBGE, 2006) and the interest in the production of small ruminants has been increasing. With this perspective, if management practices do not meet the peculiarities of the region, productive indexes will be lower than ideal, making the system unviable.

Given the above, the present study had as first objective to evaluate the effect of the suckling mode (controlled vs. continuous) and of the Amazonian climate (rainy season vs. "dry" season) on the resumption of cyclicity and postpartum fertility in Santa Inês ewes. At the same time, to make sure that these systems meet the production goals (production of meat). The effects on the lambs' weight gain were also evaluated until weaning.

\section{MATERIAL AND METHODS}

The study was conducted between September 2007 and December 2008 in a commercial farm in the North region of Brazil (01 $07^{\prime} 44^{\prime \prime S}$ and $\left.47^{\circ} 37^{\prime} 12^{\prime \prime} \mathrm{W}\right)$. That region has a climate type Am according to Köppen's classification, being characterized by two well defined seasons, rainy (December to May) and "dry" (June to November).

The study was conducted on 77 Santa Inês ewes which exhibited an average weight of $37.0 \pm 0.96$ $\mathrm{kg}$ and average age of $2.5 \pm 0.6$ years in the beginning of the experiment. The ewes were kept in a semi-intensive management system, in which they were released for grazing in amazonian quicuio grass (Brachiaria humidicola) in the morning. At the end of the day, the ewes were taken back to the pen, where they were trough fed crushed elephant grass (Pennisetum purpureum), puero (Pueraria phaseoloides) and $200 \mathrm{~g} / \mathrm{head} /$ day of $18 \%$ crude protein feed. Water and mineral salt were provided ad libitum.

For this experiment, the ewes were randomly divided into two groups according to parturition season. The rainy season group $(n=27)$ bred during the dry period (September and October/2007) and lambed during the rainy period (February and March/2008). The dry season group $(n=50)$ bred during the rainy period (March and April/2008) and lambed during the dry period (August and September/2008).

After lambing, the ewes and lambs remained confined during the first ten postpartum days. After that, the groups were randomly subdivided according to suckling mode: continuous or controlled. In the group with parturition in the rainy season, 14 ewes were selected for continuous suckling mode and 13 for controlled suckling mode. In the dry season group, the number of ewes was equally divided among the two treatments ( 25 females per group). In the continuous suckling mode, lambs were kept continuously with their mothers, following the semi-intensive management system. In the controlled suckling mode subgroup, lambs 
remained in the pen during the period while the ewes were grazing. At mid-day (12 PM), ewes would return to the pens, remaining with the lambs until 2 PM, when they were again taken to the pasture. At the end of the day, all animals would return to the pens. During the periods in which the ewes were kept in the pens, they were trough fed crushed elephant grass as a supplement and fed at the end of the day. Suckling modes were kept until weaning, 90 days postpartum. All lambs had access to creepfeeding with a commercial concentrate diet containing $18 \%$ crude protein.

The puerperium reproductive management started ten days after parturition. Four male breeders previously tested and approved for libido and seminal characteristics were kept with the ewes only during the day, separated during the night. To help in identifying females in estrus, males had their chests painted with colored grease. The color was substituted every 15 days to facilitate reproduction monitoring and control, as described by Souza and Moraes (1998). The females were observed twice a day for markings. Estrus followed by pregnancy was called conception estrus. To confirm conception, a pregnancy diagnosis was performed every 15 days using an ultrasound equipment (100 Falco Pie medical, Germany) equipped with a multi-frequency linear transducer (6.0 and 8.0 $\mathrm{MHz}$ ). In summary, transrectal ultrasound was performed with ewes in quadruped position and all portions of the uterus were observed to detect the presence of the embryonic vesicle. The ewes that were considered pregnant were examined in two other consecutive ultrasound scans to confirm diagnosis.

All ewes were weighed at the beginning of the breeding season and right after parturition. To determine the lambs' development and weight gain according to the suckling mode employed, sequential weighing was performed (at date of birth, 15, 30, 50 and 90 days after birth).

Climatic data (maximum, minimum and average temperatures; relative humidity and rainfall) were recorded each month. The temperaturehumidity index (THI) was calculated according to Thom (1958); $\mathrm{THI}=0.8 * \mathrm{~T}+(\mathrm{H} / 100) *(\mathrm{~T}-14.4)$ +46.4 , in which: $\mathrm{T}=$ environmental temperature $\left({ }^{\circ} \mathrm{C}\right) ; \mathrm{H}=$ relative humidity; average and maximum THI were considered. THI values were used to classify the thermal comfort level of the animals as: absence of stress (THI < 70); alert (between 70 and 72); critical (between 73 and 78); danger (between 79 and 82) and emergency (superior to 83; Hahn, 1985).

Data were expressed in mean and standard deviation and evaluated by ANOVA, using the General Linear Model (GLM) package of SYSTAT 7.0 statistical software (USA). The effects of the parturition season, suckling mode and their interaction with variables related to the ewes (i.e. weight and reproductive efficiency indices) and to the lambs (i.e. weight gain) were evaluated. Regression analysis to verify the lambs' weight gain (weight at birth, 15, 30, 60 and 90 days after birth) was conducted using the REG procedure in SAS system (1999). Differences were considered significant when $\mathrm{P}<0.05$ and defined as a trend when $\mathrm{P} \geq 0.05 \mathrm{e}<$ 0.10 .

\section{RESULTS}

The meteorological data allows the confirmation of two climate periods in the region (rainy and "dry", Table 1). The rainfall intensity (total volume of rain) varied between the periods (1955.1 and $720.4 \mathrm{~mL}$ for rainy and dry seasons, respectively). The average temperature-humidity indexes $\left(\mathrm{THI}_{\text {average }}\right)$ showed critical levels of thermal comfort (between 72 and 78) in both periods. Danger (between 78 and 82) and emergency $(>83)$ levels were observed when maximum indexes were calculated $\left(\mathrm{THI}_{\max }\right)$.

Data regarding the ewe's weight and reproductive efficiency indexes are shown in Table 2. Parturition season did not influence the ewe's weight (i.e. at beginning of breeding season and at parturition; $\mathrm{P}>0.05$ ). Animals subjected to controlled suckling mode exhibited reduction in intervals between parturition and first estrus with an average of 27.11 and 11.46 days for the rainy and dry seasons, respectively $(\mathrm{P}<0.05)$. As to the interval between parturition and estrus of conception (i.e. the estrus that resulted in pregnancy), a significant effect of suckling mode was seen for the dry season (reduction of an average of 13.58 days for females in the controlled suckling mode group; $\mathrm{P}<0.05)$ and a reduction trend was seen for the rainy season (difference of 12.81 days, $\mathrm{P}=0.06$ ). 
Table 1. Mean monthly temperature values (maximum - $\mathrm{T}_{\max }$; minimum $-\mathrm{T}_{\operatorname{mín}}$ and; average $-\mathrm{T}_{\text {average }}$ ), humidity, rainfall and temperature-humidity index (maximum - $\mathrm{THI}_{\max }$ and; average $-\mathrm{THI}_{\mathrm{average}}$ ) in parturition seasons (rainy and dry)

\begin{tabular}{ccccccccc}
\hline Season & Month & $\mathrm{T}_{\max }\left({ }^{\circ} \mathrm{C}\right)$ & $\begin{array}{c}\mathrm{T}_{\min } \\
\left({ }^{\circ} \mathrm{C}\right)\end{array}$ & $\begin{array}{c}\mathrm{T}_{\text {average }} \\
\left({ }^{\circ} \mathrm{C}\right)\end{array}$ & $\begin{array}{c}\text { Humidity } \\
(\%)\end{array}$ & $\begin{array}{c}\text { Rainfall } \\
\left(\mathrm{mm}^{3}\right)\end{array}$ & $\mathrm{THI}_{\max }$ & THI $_{\text {average }}$ \\
\hline \multirow{6}{*}{ Rainy } & Dec & 32.6 & 22.2 & 27.4 & 80 & 245.2 & 86 & 78 \\
& Jan & 31.0 & 22.5 & 26.7 & 79 & 292.4 & 84 & 77 \\
& Feb & 31.0 & 22.3 & 26.6 & 88 & 235.4 & 85 & 78 \\
& Mar & 29.8 & 22.4 & 26.1 & 90 & 322.2 & 84 & 77 \\
& Apr & 30.7 & 22.3 & 26.5 & 88 & 586.4 & 85 & 78 \\
& May & 31.2 & 22.5 & 26.8 & 77 & 273.5 & 84 & 77 \\
& Average & 31.1 & 22.4 & 26.7 & 83.7 & 325.9 & 84.7 & 77.5 \\
\hline \multirow{6}{*}{ Dry } & June & 31.4 & 22.2 & 26.7 & 79 & 314.7 & 85 & 77 \\
& July & 32.0 & 21.7 & 26.8 & 83 & 153.9 & 86 & 78 \\
& Aug & 32.8 & 21.7 & 27.2 & 80 & 90.6 & 87 & 78 \\
& Sept & 32.8 & 21.6 & 27.2 & 78 & 56.0 & 87 & 77 \\
& Oct & 32.3 & 21.4 & 26.8 & 79 & 47.2 & 86 & 77 \\
& Nov & 34.2 & 21.5 & 27.8 & 77 & 58.0 & 89 & 79 \\
& Average & 32.6 & 21.7 & 27.1 & 79.3 & 120.1 & 86.7 & 77.7 \\
\hline
\end{tabular}

Table 2. Summary of results of the reproductive efficiency (mean \pm S.E.M.) grouped according to the period (rainy and dry) and suckling management (continuous and controlled) in Santa Ines sheep

\begin{tabular}{|c|c|c|c|c|}
\hline \multirow{2}{*}{ Suckling } & \multicolumn{2}{|c|}{ Rainy season } & \multicolumn{2}{|c|}{ Dry season } \\
\hline & Continuous & Controlled & Continuous & Controlled \\
\hline $\begin{array}{l}\text { Ewe's weight at breeding season } \\
\text { (kg) }\end{array}$ & $39.21 \pm 6.11 \mathrm{aA}$ & $41.92 \pm 5.70 \mathrm{aC}$ & $38.53 \pm 4.28 \mathrm{cA}$ & $38.69 \pm 4.63 \mathrm{cC}$ \\
\hline Ewe's weight at parturition (Kg) & $39.51 \pm 6.20 \mathrm{aA}$ & $41.50 \pm 5.58 \mathrm{aC}$ & $40.25 \pm 4.47 \mathrm{cA}$ & $40.30 \pm 4.89 \mathrm{cC}$ \\
\hline $\begin{array}{l}\text { Interval Parturition and } 1 \text { st estrus } \\
\text { (day) }\end{array}$ & $57.64 \pm 18.24 \mathrm{aA}$ & $30.53 \pm 10.93 \mathrm{bC}$ & $39.30 \pm 8.74 \mathrm{cB}$ & $27.84 \pm 5.39 \mathrm{dC}$ \\
\hline $\begin{array}{l}\text { Interval Parturition and estrus of } \\
\text { conception (days) }\end{array}$ & $71.50 \pm 16.47 \mathrm{eA}$ & $58.69 \pm 17.32 \mathrm{fC}$ & $58.50 \pm 9.10 \mathrm{cB}$ & $44.92 \pm 6.62 \mathrm{dD}$ \\
\hline $\begin{array}{l}\text { Interval between parturitions } \\
\text { (days) }\end{array}$ & $221 \pm 17.23 \mathrm{eA}$ & $208 \pm 16.56 \mathrm{fC}$ & $208 \pm 10.01 \mathrm{cB}$ & $194 \pm 6.34 \mathrm{dD}$ \\
\hline
\end{tabular}

Different letters in the same row indicate differences at $\mathrm{P}<0.05$ ( $\mathrm{a} \neq \mathrm{b}$ e $\mathrm{c} \neq \mathrm{d}$, on periods; $\mathrm{A} \neq \mathrm{B}$ e $\mathrm{C} \neq \mathrm{D}$, between periods) or $\mathrm{P}<0.10$ (tendency; $\mathrm{e} \neq \mathrm{f}$ ).

The effect of the parturition season on the interval between parturition and first estrus was observed for ewes subjected to continuous suckling mode (reduction of an average of 18.34 days for the group with parturition in the dry season; P>0.05). Similarly, conceptions occurred earlier in ewes with parturition in the dry season (i.e. interval of parturition - estrus of conception was shorter when parturition occurred in the dry season, $\mathrm{P}>0.05$ ), regardless of the suckling mode employed. The same behavior was observed for the interval between parturitions.

Results regarding the lambs' weight gain up to weaning are shown in Table 3. The lambs' weight at birth did not vary between treatments $(\mathrm{P}>0.05)$. The suckling mode only exhibited an effect on weight up to weaning on lambs born in the rainy season; higher weights were seen for lambs subjected to controlled suckling $(\mathrm{P}<0.05)$. As to the dry period, no variation was observed in regard to lambs' management $(\mathrm{P}>0.05)$. An effect of birth season was only seen in the subgroup that was subjected to continuous suckling mode; there was higher weight gain for lambs born in the dry period $(\mathrm{P}<0.05)$. For lambs subjected to controlled suckling, the only differentiated development was seen between periods, without exhibiting, however, a variation in weaning weight. 
The effects of parturition...

Table 3. Summary of weight performance results (mean \pm S.E.M.) grouped according to the period (rainy and dry) and suckling management (continuous and controlled) in Santa Ines sheep

\begin{tabular}{|c|c|c|c|c|}
\hline \multirow{2}{*}{ Suckling } & \multicolumn{2}{|c|}{ Rainy season } & \multicolumn{2}{|c|}{ Dry season } \\
\hline & Continuous & Controlled & Continuous & Controlled \\
\hline Lambs' weight at birth (kg) & $3.69 \pm 0.12 \mathrm{aA}$ & $3.73 \pm 0.13 \mathrm{aC}$ & $3.47 \pm 0.12 \mathrm{cA}$ & $3.71 \pm 0.10 \mathrm{cC}$ \\
\hline $\begin{array}{l}\text { Lambs' weight at } 15 \text { days old } \\
(\mathrm{kg})\end{array}$ & $6.67 \pm 0.34 \mathrm{aA}$ & $8.14 \pm 0.20 \mathrm{bC}$ & $6.73 \pm 0.19 \mathrm{cA}$ & $6.66 \pm 0.43 \mathrm{cD}$ \\
\hline $\begin{array}{l}\text { Lambs' weight at } 30 \text { days old } \\
(\mathrm{kg})\end{array}$ & $8.85 \pm 0.42 \mathrm{aA}$ & $11.16 \pm 0.25 \mathrm{bC}$ & $9.66 \pm 0.35 \mathrm{cA}$ & $10.01 \pm 0.82 \mathrm{cD}$ \\
\hline $\begin{array}{l}\text { Lambs' weight at } 60 \text { days old } \\
(\mathrm{kg})\end{array}$ & $11.58 \pm 0.54 \mathrm{aA}$ & $14.82 \pm 0.41 b C$ & $14.31 \pm 0.46 \mathrm{cB}$ & $13.64 \pm 1.21 \mathrm{cD}$ \\
\hline $\begin{array}{l}\text { Lambs' weight at } 90 \text { days old } \\
\text { (kg) }\end{array}$ & $13.95 \pm 0.52 \mathrm{aA}$ & $17.83 \pm 0.56 b C$ & $18.20 \pm 0.60 \mathrm{cB}$ & $18.78 \pm 1.20 \mathrm{cC}$ \\
\hline
\end{tabular}

Regression analysis allowed us to confirm the effects of treatments on lambs weight gain (Figure 1). All animals showed significant weight gain throughout the observation period $(\mathrm{P}<0.05)$. In the rainy season, daily weight gain was higher for the subgroup subjected to controlled suckling mode (156 vs. $113 \mathrm{~g} /$ day, $\mathrm{P}>0.05)$. No difference was observed between subgroups born in the dry period (167 vs. $163 \mathrm{~g} /$ day for controlled and continuous suckling, respectively; $\mathrm{P}>0.05$ ).

\section{Rainy season}
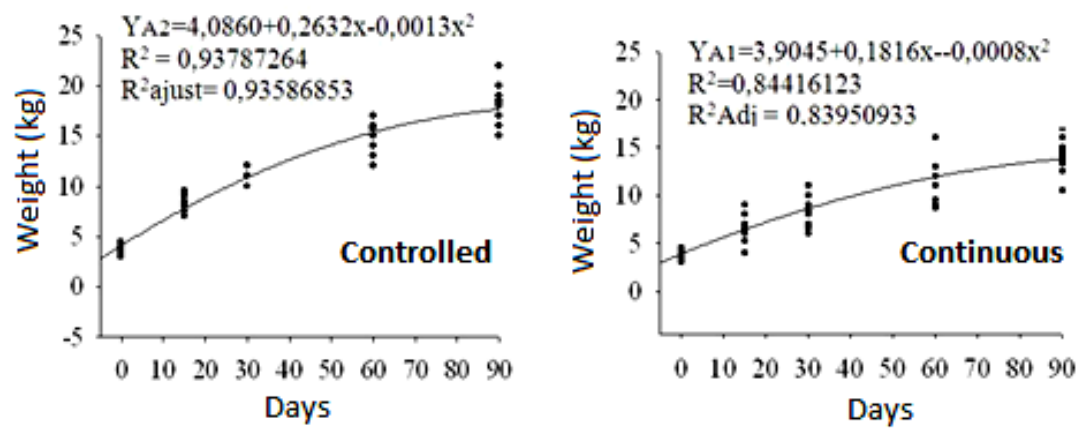

Dry season
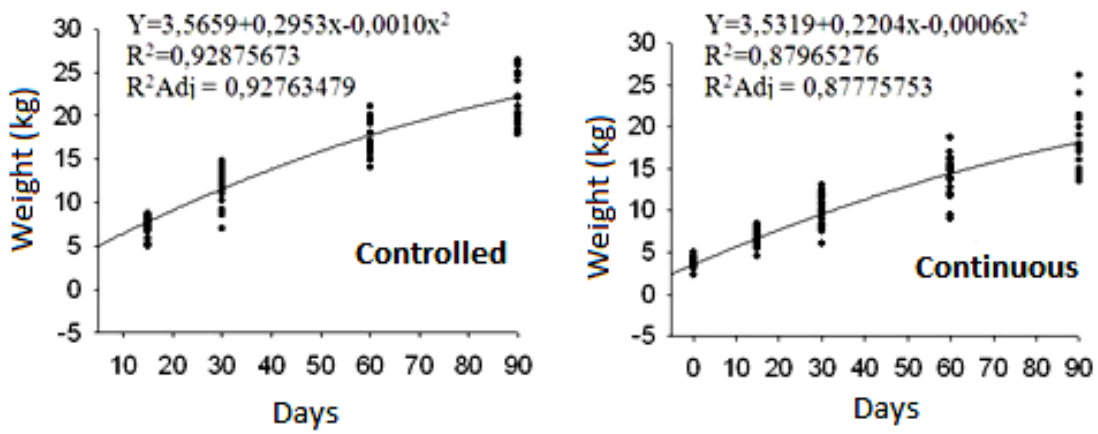

Figure 1. Regression curve according to the equations for the weights of Santa Ines lambs until weaning according to the birth season (rainy and dry) and suckling management (controlled and continuous). 


\section{DISCUSSION}

Knowledge regarding climate variables, their interaction with the animals and the behavioral, physiological and productive responses are crucial when adjusting a production system to its main objectives (Neiva et al., 2004). The climate difference between the periods was restricted to rainfall. Even though the rainfall potentially interfered with grazing time, there was no compromise in food supply owing to the fact that the diet was supplemented to meet the daily requirements. This can be confirmed by the absence of variation in the ewes' weight when comparing both seasons. This way, nutritional factors were eliminated within the variables studied, as this was not the focus of this study. In the same manner, the estimated comfort of the animals under the climate conditions (temperature and humidity) remained constant. Even though critical levels were observed, no correlation to any factor studied was seen; however, we highlight the need to implement management practices that favor the comfort of the animals (i.e. areas providing shade and shelter from rain in the pasture, access to abundant water, etc.).

When the controlled suckling mode was employed, the interval between parturition and first estrus was reduced, regardless of the parturition season. This anticipation of resumption of ovarian cyclicity shows the intimate relation between the suckling stimulus (i.e. suckling of the teats and milk production) and its endocrine suppression of the ovarian function (Pollot and Gootwine, 2004; Montiel and Ahuja, 2005). This stimulus reduces the hypothalamus' release of GnRH which results in insufficient pulsatile secretion of LH (Williams, 1990). In other words, the pattern of follicular waves is present right after parturition; however, follicles do not complete their growth and maturation due to reduced secretion of $\mathrm{LH}$ (Wiltbank et al., 2002). In these conditions, estrus behavior and ovulation are not observed. When the inhibitory factors are reduced or removed, there is reestablishment of cyclicity. This confirms the positive effect of controlled suckling mode on the reduction of the interval between parturition and first estrus. This result corroborates findings by Souza et al. (1996); however, it is in disagreement with findings by Azevedo et al. (2002) and Costa et al. (2007), which did not obtain significant positive effects from postpartum management in ewes.

Resumption of cyclicity is not always associated with the beginning of a new pregnancy. The interval between parturition and conception estrus is what effectively shows the unproductive period of the ewe. Therefore, a reduction observed for this variable under the control of suckling mode indicates that the management practice is being effective due to the reproductive performance of the female. A similar effect was described by Morales-Terán et al. (2004). The shortening of the ewes' postpartum period up to the next conception allows the establishment of three parturitions every two years, in other words, parturition intervals of eight months. This is considered the ideal system for raising slaughter lambs (Roda et al., 1993; Otto de Sá, 2002).

The season in which parturitions occurred had an effect over variables related to the reproductive efficiency of the ewes. The shorter period of resumption of cyclicity and fertility of females with parturition in the dry period could possibly be related to the "stress" caused to the animals by heavy rains during the rainy period. Mies Filho (1988) suggests that the rainy season can affect the hormonal secretion profile and thus, has an important effect on the reproductive performance. Even though it is a possible explanation, there are no studies that prove the mechanism involved with this effect. It is important to highlight that the comfort index of the animals estimated in the present study was based solely on THI, calculated from temperature and humidity data. On the other hand, the incidence of hoof problems, parasitosis and respiratory infections are higher in the rainy season and can also have an effect on the reproductive efficiency of the animals. Based on these possible explanations, the need to develop management practices that address environmental peculiarities and their interaction with animals should be reinforced.

Based on the main goal of Santa Ines sheep raising (i.e. production of meat; Coelho et al., 2006), the evaluation of effects (suckling management and parturition season) on lambs' weight gain is essential. The variations observed for lambs' weight gain throughout the suckling period reinforce the "stress" that animals go 
through during frequent and intense rains. Due to the climate conditions during the rainy season, a lower weight gain was seen for lambs born during that period, especially those subjected to continuous suckling mode (lambs that would remain with the mothers in the pasture throughout the whole day). This is confirmed by a lack of difference between birth periods when comparing animals subjected to controlled suckling mode. Under this mode, high rainfall is not expected to affect the animals' behavior.

\section{CONCLUSION}

Controlled suckling mode, in both dry and rainy seasons, is the most suitable management mode for the Eastern Amazonian region since it results in a shorter puerperium for the ewes and higher weight gain for the lambs. Therefore, the initial hypothesis of the study was confirmed. The improvement of these indexes enables better reproductive and productive efficiency of the herd.

\section{ACKNOWLEDGEMENTS}

We thank the CNPq/CAPES (Ação Transversal $n^{\text {o }}$ 06/2011 Casadinho/Procad), CNPq (Postdoctoral scholarship) and State of Sao Paulo Research Foundation (FAPESP, Brazil).

\section{REFERÊNCIAS}

AZEVEDO, J.M.; CORREIA, T.M.; ALMEIDA, J.C. et al. Anestro pós-parto em ovelhas de diferentes raças. Efeitos do regime de amamentação. Rev. Port. Cienc. Vet., v.97, p.129-134, 2002.

COELHO, L.A.; RODRIGUES, P.A.; NONAKA, K.O. et al. Annual pattern of plasma melatonin and progesterone concentrations in hair and wool ewe lambs kept under natural photoperiod at lower latitudes in the southern hemisphere. J. Pineal Res., v.41, p.101-107, 2006.

COSTA, R.L.D.; CUNHA, E.A.; FONTES, R.S. et al. Desempenho reprodutivo de ovelhas Santa Inês submetidas à amamentação contínua ou controlada. Bol. Indust. An., v.64, p.51-59, 2007.

COSTA, E.P.S.; TAKEDA, F.R.P.C.; LIMA, R.S. Avaliação da Adaptabilidade de Ovinos Santa Inês ao Clima Amazônico. REDVET. Rev. Electr. Vet., v.11, p.1-8, 2010.
HAHN, G.L. Management and housing of farm animals in hot environments. In: YOUSEF, M.K. Stress physiology in livestock, v.2 (Ed.). Boca Raton: CRC Press, 1985. p.151-174.

HAYDER, M.; ALI, A. Factors affecting the postpartum uterine involution and luteal function of sheep in the subtropics. Small Rum. Res., v.79, p.174178, 2008.

IBGE - Instituto Brasileiro de Geografia e Estatística. Produção da Pecuária Estadual. 2006. Disponível em: http://www.ibge.gov.br/estadosat/temas.php?sigla=pa \&tema=censoagro. Acessado em: 20 mai. 2011.

MANDIKI, S.N.M.; BISTER, J.L.; PAQUAY, R. Effects of suckling mode on endocrine control of reproductive activity resumption in Texel ewes lambing in July or November. Theriogenology, v.33, p.397-413, 1990.

MIES FILHO, A. Tecnologia do sêmen e inseminação artificial na espécie ovina. In: CONGRESSO BRASILEIRO DE REPRODUÇÃO ANIMAL, 7., 1988, Campinas. Anais... Campinas: 1988. p.1-16.

MONTIEL, F.; AHUJA, C. Body condition and suckling as factors influencing the duration of postpartum anestrus in cattle: a review. An. Reprod. Sci., v.85, p.1-26, 2005.

MORALES-TÉRAN, G.; PRO-MARTÍNEZ， A.; FIGUEROA-SANDOVAL, B. et al. Amamantamiento continuo o restringido y su relación con la duración del anestro postparto en ovejas Pelibuey. Agrociencia, v.38, p.165-171, 2004.

NEGRÃO, J.A.; MARNET, P.G.; LABUSSIÈRE, J. Effect of milking frequency on oxytocin release and milk production in dairy ewes. Small Rum. Res., v.39, p.181-187, 2001.

NEIVA, J.N.M.; TEIXEIRA, M.; TURCO, S.H.N. et al. Efeito do estresse climático sobre os parâmetros produtivos e fisiológicos de ovinos Santa Inês mantidos em confinamento na região litorânea do nordeste do Brasil. Rev. Bras. Zootec., v.33, p.668678,2004

OTTO DE SÁ, C. Manejo reprodutivo para intervalo entre partos de oito meses. In: SIMPÓSIO PAULISTA DE OVINOCULTURA, 6., 2002, Botucatu. Anais... Botucatu: 2002. p.8-20.

POLLOTT, G.E.; GOOTWINE, E. Reproductive performance and milk production of Assaf sheep in an intensive management system. J. Dairy Sci., v.87, p.3690-3703, 2004.

RODA, D.S.; SANTOS, L.E.; CUNHA, E.A. et al. Performance of ewes mated at intervals of eight months. Bol. Indust. An., v.50, p.49-54, 1993. 
RONQUILLO, J.C.C.; MARTÍNEZ, A.P.; PÉREZ, C.M.B. et al. Prevention of suckling improves postpartum reproductive responses to hormone treatments in Pelibuey ewes. Anim. Reprod. Sci., v.107, p.85-93, 2008.

SAS Institute Inc. (1999), SAS, Version 8, Cary, NC: SAS Institute Inc.

SOUZA, C.J.; MORAES, J.C.F. Manual de sincronização de cios em bovinos e ovinos. Bagé: Embrapa Pecuária Sul, Comunicado Técnico 13, 1998. p.1-75.

SOUZA, P.H.F.; RODRIGUES, M.R.C.; SIMPLÍCIO, A.A. Efeito da amamentação sobre o desempenho produtivo pós-parto de ovinos da raça Santa Inês, mantidos em pastagem nativa durante a época chuvosa, Cienc. An., v.6, p.20-27, 1996.
THOM, E.C. Cooling degree"day air conditioning, heating, and ventilating. In: TRANSACTIONS OF THE AMERICAN SOCIETY HEATING REFRIGERATION AIRCONDITIONNING ENGRS, 55., 1958. p.65-72.

WILLIAMS, G.L. Suckling as a regulator of postpartum rebreeding in cattle: a review. J. Anim. Sci., v.68, p.831-852, 1990.

WILTBANK, M.C.; GTIMEN, A.; SARTORI, R. Physiological classification of anovulatory conditions in cattle. Theriogenology, v.57, p.21-52, 2002.

YAVAS, T.; WALTON, J.S. Postpartum acyclicity in suckled beef cows: a review. Theriogenology, v.54, p.25-55, 2000. 